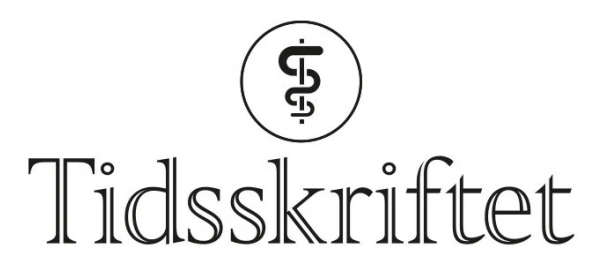

DEN NORSKE LEGEFORENING

\title{
Herpes zoster oticus
}

\author{
KORT KASUISTIKK
}

SILJE HOLT JAHR

siljehja@uio.no

Nevroklinikken

Akershus universitetssykehus

og

Institutt for klinisk medisin

Universitetet i Oslo

Silje Holt Jahr er lege i spesialisering og klinisk stipendiat.

Forfatteren har fylt ut ICMJE-skjemaet og oppgir ingen interessekonflikter.

\section{MARIA SOLBERG WAHL}

Øre-nese-hals-avdelingen

Akershus universitetssykehus

Maria Solberg Wahl er lege i spesialisering.

Forfatteren har fylt ut ICMJE-skjemaet og oppgir ingen interessekonflikter.

\section{BILAL MAJID}

Bildediagnostisk avdeling

Akershus universitetssykehus

Bilal Majid er lege i spesialisering.

Forfatteren har fylt ut ICMJE-skjemaet og oppgir ingen interessekonflikter.

\section{ELLEN SAMUELSEN}

Infeksjonsmedisinsk avdeling

Akershus universitetssykehus

Ellen Samuelsen er spesialist i infeksjonssykdommer og overlege.

Forfatteren har fylt ut ICMJE-skjemaet og oppgir ingen interessekonflikter.

\section{Perifer facialisparese har flere årsaker. Ledsagende utslett, smerter i øret og eventuelt tegn på samtidig affeksjon av andre hjernenerver gir mistanke om herpes zoster oticus.}

En kvinne i 6o-årene med hypertensjon, astma, urinsyregikt og tinnitus ble innlagt på nevrologisk avdeling grunnet nyoppstått, venstresidig ansiktsskjevhet. Ved innkomst hadde kvinnen manglende evne til å rynke pannen og løfte øyebrynet samt lagoftalmus (åpentstående øye) på venstre side. Hun hadde også utvisket nasolabialfure, asymmetrisk smil, redusert tåre- og spyttproduksjon og lydømfintlighet på venstre side, forenlig med en komplett, perifer affeksjon av facialisnerven (CN VII), House-Brackmann grad VI (gradering 
av ansiktslammelse fra I til VI) (1). Kvinnen bemerket imidlertid ingen større smaksendringer. I tillegg hadde hun de siste par dagene vært plaget med en relativt raskt debuterende, rotatorisk svimmelhet som ble forverret ved bevegelse, samt endret hørsel og $\emptyset$ mhet i øregang på venstre side.

Ved undersøkelse ble det konstatert horisontal nystagmus i rask fase mot høyre og positiv hodeimpulstest mot venstre. Det var også redusert hørsel på venstre side, med bedre luftledning enn benledning bilateralt ved Rinnes prøve. Webers prøve viste lateralisering mot høyre, forenlig med sensorinevralt hørseltap på venstre side. Rentoneaudiometri avdekket et moderat, nevrogent hørselstap på venstre side, med gjennomsnittlig høreterskel (svakeste lyden man kan høre) på 55 desibel (o-20 dB). Funnene var forenlig med affeksjon av venstre sides vestibulocochlearisnerve (CN VIII). Øvrig nevrologisk undersøkelse viste normale funn. Pasienten fremstod i redusert allmenntilstand, men uten feber, hodepine, nakkestivhet eller lysskyhet. Det var normale funn på blodprøver, spesielt var ingen avvikende infeksjonsprøver (leukocytter, CRP og senkning).

MR av hodet ble beskrevet som normalt, med unntak av flekkvise, uspesifikke høysignalforandringer supratentorialt. For å utelukke inflammasjon ble det utført lumbalpunksjon, som viste forhøyet leukocyttall i cerebrospinalvæsken, med $45 \cdot 10^{6} / \mathrm{L}$ (o-4 $\cdot 10^{6} / \mathrm{L}$ ), samtlige mononukleære celler. For $\emptyset$ vrig var glukose- og proteinverdier i spinalvæsken normale, og det var fravær av intratekal IgG-produksjon.

Polymerasekjedereaksjonstest (PCR) for varicella-zoster-virus var positiv i spinalvæsken.

Initialt var det ingen hud- eller slimhinneforandringer, men en uke etter symptomdebut tilkom små vesikler i dypet av venstre øremusling (figur 1) og noen få vesikler i ganen på venstre side. Pasienten hadde funn forenlig med herpes zoster oticus med affeksjon av hjernenerve VII og VIII. Antiviral behandling per os med valaciklovir 1 ooo $\mathrm{mg} \times 3$ i syv dager i kombinasjon med oral prednisolon $1 \mathrm{mg} / \mathrm{kg}$ i fem dager $(\underline{2}, 3)$ ble igangsatt. I tillegg startet man med øyebeskyttende tiltak i form av kunstig tårevæske og tildekking (2). 


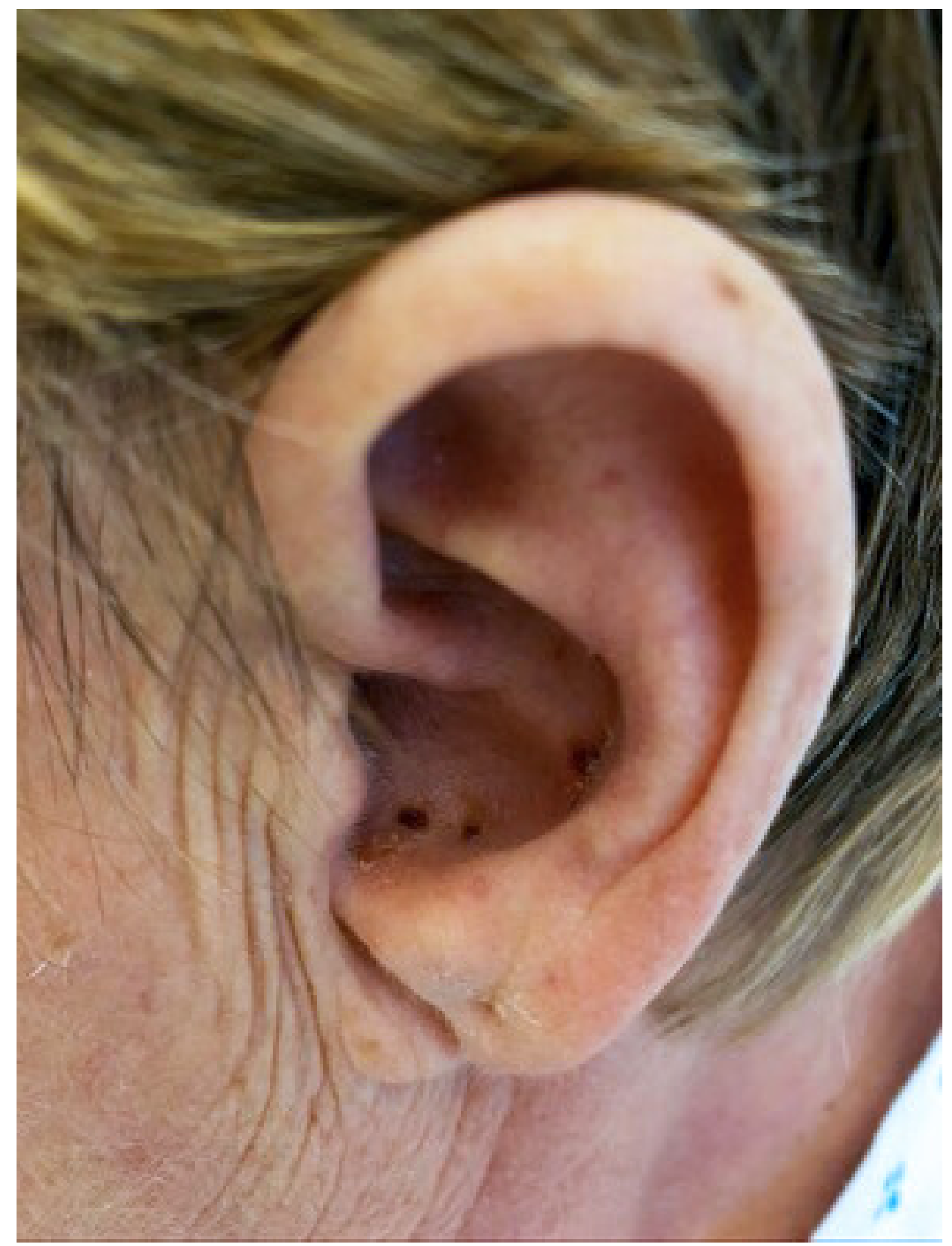

Figur 1 Utslett med vesikler og kruster i øremuslingen venstre side.

Tre dager senere ble pasienten reinnlagt grunnet forverring av svimmelhet og kvalme. Ny MR av hodet viste tegn til inflammasjon, med økt kontrastoppladning i indre øregang og langs facialisnervens tympaniske og mastoide segment på venstre side (T1-vektede bilder) (figur 2) og økt signal i indre øregang i både cochlea og vestibularisapparatet på venstre side (FLAIR SPIR-sekvenser). Videonystagmoskopi med kalorisk testing viste $56 \%$ svakere respons på venstre side, som tegn på redusert funksjon i vestibularisnerven. Det ble bemerket et kløende, papuløst utslett i hodebunnen. Dette var en sannsynlig bivirkning av valaciklovir. 


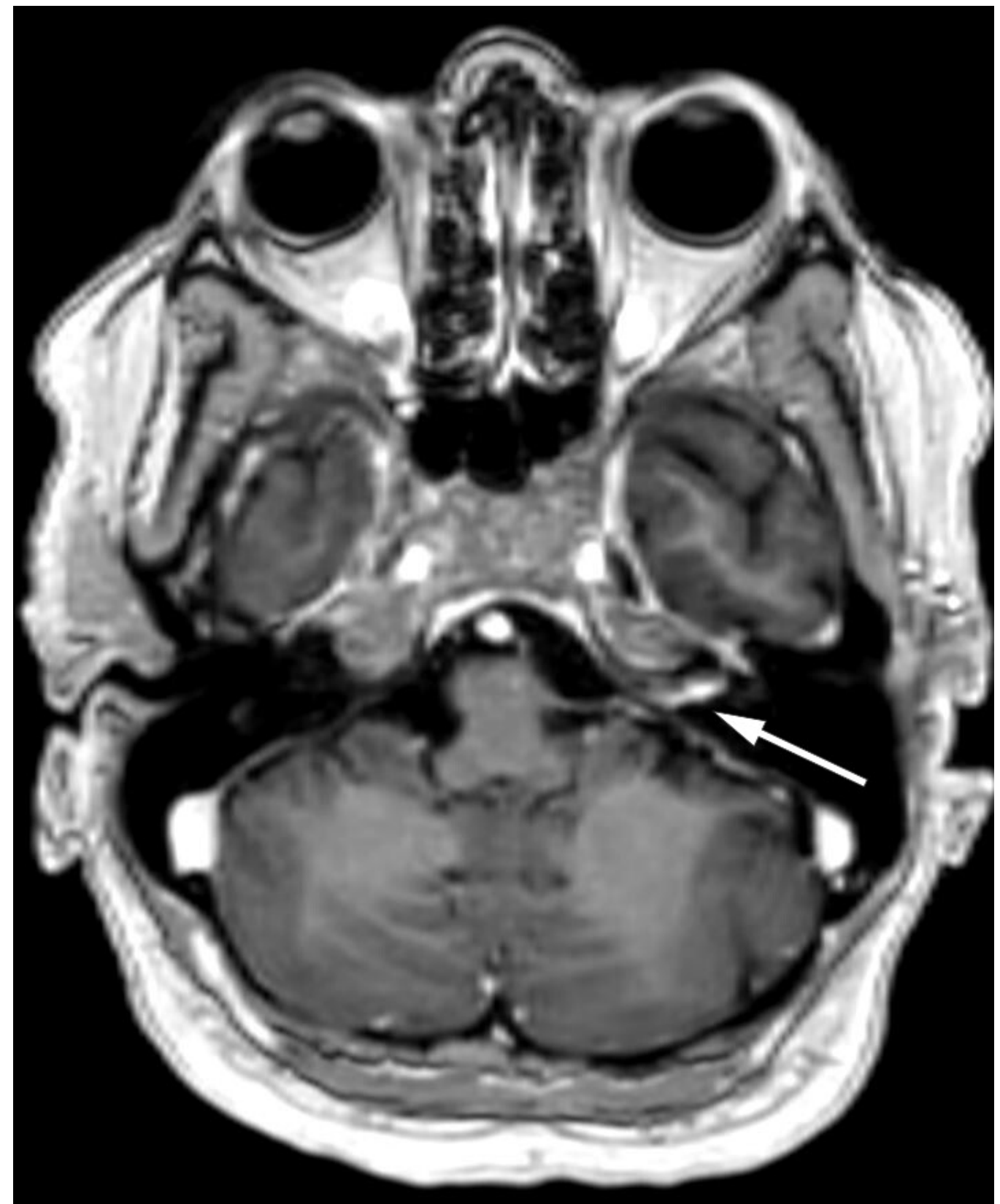

Figur 2 Aksialt MR-bilde av hodet (T1-vekting med intravenøs kontrast) viser økt

kontrastoppladning i venstre indre øregang og langs facialisnervens tympaniske og mastoide segment (pil).

Behandlingsperioden med prednisolon og valaciklovir ble forlenget, men med sistnevnte i redusert dosering. Pasienten ble skrevet ut med oppfølging hos kommunal fysioterapeut og til vestibulær rehabilitering på svimmelhetspoliklinikk. Ved kontroll etter en måneds tid var svimmelheten gått over, men pasienten hadde fremdeles redusert hørsel og facialisparalyse.

\section{Diskusjon}

Herpes zoster oticus er en ensidig, perifer facialisparese kombinert med smerter og vesikulært utslett i øret og/eller orale slimhinner på den samme siden. Tilstanden ble beskrevet av nevrologen James Ramsay Hunt (1872-1937) i 1907 og kalles derfor også Ramsay Hunts syndrom eller Hunts syndrom (4.). Årsaken er reaktivering av latente varicella-zostervirus (VZV) i sensoriske ganglion geniculatum i facialisnerven etter tidligere infeksjon med vannkopper (varicella). Syndromet er ofte assosiert med involvering av andre hjernenerver, oftest vestibulocochlearisnerven (CN VIII) grunnet dens nære beliggenhet til facialisnerven (5). 
Herpes zoster manifesterer seg sjelden som herpes zoster oticus. Imidlertid utgjør herpes zoster oticus $12 \%$ av alle perifere facialispareser ( $(\underline{6})$. Det oppstår i alle aldre, hyppigst hos dem over 45 år (7.). Tilstanden kan initialt være vanskelig å skille klinisk fra idiopatisk, perifer facialisparese, også kjent som Bells parese, da omtrent $15 \%$ utvikler utslett først etter debut av ansiktslammelse. Hos et fåtall av pasientene er utslettet helt fraværende (zoster sine herpete $(\mathrm{ZSH}))(5)$. Facialisparesen ved herpes zoster oticus er ofte mer alvorlig, med mindre sannsynlighet for komplett tilheling enn ved idiopatisk, perifer facialisparese ( $\underline{6}$, 7.).

Diagnosen stilles hovedsakelig basert på anamnese og kliniske funn (5). Undersøkelse av spinalvæske og MR av hodet har liten diagnostisk eller prognostisk verdi. Virus kan imidlertid påvises ved PCR-undersøkelse fra vesikuløst utslett, tårer, spytt eller spinalvæske (ㅁ).

Behandlingsmessig foreligger få randomiserte, kontrollerte prospektive studier (9.), men data fra kasuistikker og retrospektive studier indikerer at tidlig diagnostisering med rask oppstart av antiviral behandling (aciklovir/valaciklovir) i kombinasjon med steroider

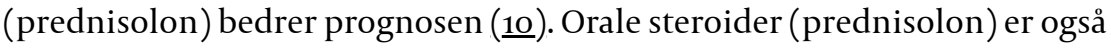
standardbehandling ved idiopatisk, perifer facialisparese (2). Antiviral tilleggsbehandling er imidlertid omdiskutert, men er antakelig både effektivt og trygt og anbefales spesielt ved alvorlige pareser (ㅁ). Vi mener at lav terskel for antiviral tilleggsbehandling ved antatt idiopatisk, perifer facialisparese, spesielt hos eldre ved uttalte pareser og ubehag i øret medfører at utfordrende tilfeller av herpes zoster oticus med forsinkelse av eller fravær av utslett blir adekvat behandlet uten behov for supplerende undersøkelser.

Pasienten har gitt samtykke til at artikkelen blir publisert. Artikkelen er fagfellevurdert.

\section{LITTERATUR}

1. House JW, Brackmann DE. Facial nerve grading system. Otolaryngol Head Neck Surg 1985; 93: 146-7. [PubMed][CrossRef]

2. Ljøstad U. Akutt perifer facialisparese. Norsk Elektronisk Legehåndbok (NEL) Nevrologi. Oppdatert 12.10.2020. https://nevrologi.legehandboka.no/handboken/symptomer/akutt-perifer-facialisparese/ Lest 23.2.2021.

3. Albrecht MA. Treatmentof herpes zoster in the immunocompetent host. UpToDate. Oppdatert 11.3.2020. https://www.uptodate.com/contents/treatment-of-herpes-zoster-in-the-immunocompetenthost?search=treatment-of-herpes-zoster-in-the-

immunocompetenthost\&source=search_result\&selectedTitle=1 $\sim 150 \&$ usage_type=default\&display_r ank $=1$ Lest 23.2.2021.

4. Hunt JR. On herpetic inflammations of the geniculate ganglion. A new syndrome and its complications. J Nerv Ment Dis 1907; 34: 73-96. [CrossRef]

5. Sweeney CJ, Gilden DH. Ramsay Hunt syndrome. J Neurol Neurosurg Psychiatry 2001; 71: 149-54. [PubMed][CrossRef]

6. Robillard RB, Hilsinger RL, Adour KK. Ramsay Hunt facial paralysis: clinical analyses of 185 patients. Otolaryngol Head Neck Surg 1986; 95: 292-7. [PubMed][CrossRef]

7. Peitersen E. Bell's palsy: the spontaneous course of 2,500 peripheral facial nerve palsies of different etiologies. Acta Otolaryngol Suppl 2002; 549: 4-30. [PubMed][CrossRef]

8. Sauerbrei A, Eichhorn U, Schacke M et al. Laboratory diagnosis of herpes zoster. J Clin Virol 1999; 14: 31-6. [PubMed][CrossRef]

9. Uscategui T, Dorée C, Chamberlain IJ et al. Antiviral therapy for Ramsay Hunt syndrome (herpes zoster oticus with facial palsy) in adults. Cochrane Database Syst Rev 2008; 4: CDoo6851. [PubMed] [CrossRef]

10. Monsanto RdC. Bittencourt AG, Bobato Neto NJ, Beilke SCA, Lorenzetti FTM, Salomone R.

Treatment and Prognosis of Facial Palsy on Ramsay Hunt Syndrome: Results Based on a Review of the Literature. Int Arch Otorhinolaryngol 2016; 20:394-40o. [CrossRef] 
Publisert: 25. oktober 2021. Tidsskr Nor Legeforen. DOI: 10.4045/tidsskr.21.0036

Mottatt 12.1.2021, første revisjon innsendt 18.3.2021, godkjent 21.5.2021.

Publisert under åpen tilgang CC BY-ND. Lastet ned fra tidsskriftet.no 26. april 2023. 